\title{
Elements of Strategic Management Process and Performance Management Systems in U.S. Federal Agencies: Do Employee Managerial Levels Matter?
}

\author{
Yongjin $\mathrm{Sa}^{1}$ \\ ${ }^{1}$ School of Public and International Affairs, University of Baltimore, Baltimore, MD, USA \\ Correspondence: Yongjin Sa, School of Public and International Affairs, University of Baltimore, Baltimore, \\ MD, USA. E-mail: yongjinsa@gmail.com
}

Received: Jaunary 27, 2013

Accepted: February 16, 2013

Online Published: April 14, 2013

doi:10.5539/ijbm.v8n9p1

URL: http://dx.doi.org/10.5539/ijbm.v8n9p1

\begin{abstract}
This study examines the relationship between strategic planning components and performance-based management systems in U.S. federal agencies. This research explores the correlation between government employee perception regarding strategic planning components in agencies and three dimensions of performance management systems (performance-based promotions or rewards, fairness and accuracy of performance appraisal, and managerial efforts to improve performance). This study also explores whether the perceived correlation differs across five managerial levels (non-supervisor, team leader, supervisor, manager and executive). This study explores data from the 2008 Federal Human Capital Survey (FHCS), conducted by the U.S. Office of Personnel Management (OPM). This study conducts a total of 15 regression analyses for the three dependent variables and the five supervisor levels. In the models, all five components of strategic planning are positively correlated with the three dimensions of performance management systems among all five supervisor levels. A series of regression analyses demonstrates that the correlation differs depending on the managerial level of the employee. Employees at different managerial levels have different perceptions of the correlation between strategic planning components and each dimension of performance management systems in the public sector.
\end{abstract}

Keywords: strategic planning, strategic management elements, performance management system, employee managerial level

\section{Introduction and Literature Review}

\subsection{Strategic Planning, Management and Performance}

Theoretical and empirical relationships between strategic planning and performance or performance management have been discussed in relation to both the private and public sector. For example, Miller \& Cardinal (1994: 1650) discuss "a simple planning-performance model", which signals that a high level of strategic planning leads to a high level of profit performance. The authors explore the different effects of strategic planning on firm performance using three context variables, "firm size", "capital intensity" and "turbulence" (Miller \& Cardinal, 1994, 1650-1652), by conducting a meta-analysis based on thirty-five previously published studies in planning-performance literature. The authors demonstrate a positive correlation between strategic planning and organizational performance; however, they also mention that the variation in the relationship depends on contextual factors faced by the organization as well as the method used in the study. Chakravarthy (1987) notes the importance of environmental and organizational determinants on the relationship between strategic planning and performance.

Research on the effects of strategic planning or management on organizational performance in the private sector has primarily been based on empirical data analysis, but few studies have empirically examined this relationship in the public sector (Hendrick, 2003). Nutt \& Backoff (1993, pp. 211-212) note the distinctive differences that exist among private, nonprofit and public organizations in terms of "environmental", "transactional" and “organizational process" factors. In addition, Ring \& Perry (1985) discuss various types of contextual factors and constraints specific to the public sector that influence strategic management. Managers in the public sector would benefit from a perception of these differences and the ability to apply more efficient private sector 
strategic planning and management approaches (Nutt \& Backoff, 1993; Ring \& Perry, 1985). Performance and goals are not easily quantifiable and measurable in the public sector (Behn, 2003; Chun \& Rainey, 2005); more external environmental factors such as politics and various interest groups influence strategic planning and management (Bryson, 2011; Nutt \& Backoff, 1993; Ring \& Perry, 1985; Hendrick, 2003). These external factors may explain why few studies have empirically examined the relationship between strategic planning and performance in the public sector.

Hendrick (2003) explores the relationship between strategic planning and performance in the public sector using contextual variables such as uncertainty of objectives or their measurability and internal and external environmental factors. The results are based on survey data from fourteen departments within the City of Milwaukee. Hendrick (2003) finds that particular strategic planning processes, including communication, monitoring and coordination, show a positive relationship with organizational performance, some internal and external environments; in addition, the level of goal congruence influences both the planning process and performance. Hendrick (2003) notes that participant satisfaction with the planning and implementation process influences the relationship between strategic planning and organizational performance, as argued by other strategic planning studies (Bryson, 2011; Boal \& Bryson, 1987; Nutt, 1986).

Studies in the planning-performance literature on the relationship between the planning process, contextual factors (e.g., organizational external and internal environment) and organizational performance have differing results and implications. However, studies generally assume that the level of fitness between planning processes and contextual variables is a fundamental factor influencing performance in the public sector. Boal \& Bryson (1987) outline three types of relationships regarding planning processes, contextual factors and performance: 1) the effect of context on the planning process directly influences performance. 2) context and the planning process influence performance jointly and independently. and 3) contextual influences on the relationship between the planning process and organizational performance are a moderating factor.

\subsection{Strategic Management Elements and Performance Management System: Employee Managerial Levels}

What are the linkages between strategic management elements and performance measurement or the performance management system? In other words, beyond exploring the direct relationship between strategic management or the implementation process and organizational performance, as discussed above, what is the linkage between performance management systems and particular elements of the strategic management process in the public sector? According to Bryson's (2011: 323) discussion, "performance measurement systems (or performance management systems or results-based management systems) are ongoing organizational designs or arrangements for strategically managing the implementation of agreed-upon strategies, assessing the performance of those strategies, and formulating new or revised strategies". Furthermore, he argues that performance management systems, or performance measures, play a significant role in connecting the missions, goals, vision or objectives of an organization with success in creating public value at a reasonable cost (Bryson, 2011). The development of performance management systems is therefore a critical component for successful strategic planning and implementation.

This discussion leads to a new hypothesis: an agency possessing a higher level of well-functioning strategic planning/management components is likely to have a more developed performance management system. What strategic management elements (such as information and communication strategy, mission and goal clarification, employee empowerment and involvement in decision making) are correlated with improved performance management or measurement systems in public organizations? How do the linkages differ? This is the first primary research question explored in this study.

Poister \& Streib (2005) explore this correlation by surveying municipal officials representing all U.S. cities with a population over 25,000 . The survey explores the officials' perceptions of the correlation between performance management or performance measures and strategic planning. Poister \& Streib (2005) indicate that a high percentage of the municipal officials reported that they currently have a well-functioning performance management system as well as a strong, direct linkage between strategic planning and performance measures or management systems.

However, the results and implications from Poister \& Streib (2005) are based on input from senior level public government officials and directors. The perceptions of other managerial levels (e.g., non-supervisors and team leaders) are still not clear in the strategic planning-performance literature. Rainey \& Bozeman (2000: 452) mention that managers in the public sector are likely to report a higher level of positive evaluation regarding overall management systems, managerial capacity and organizational performance in their organizations because of the "social desirability response". 
Empirical results from studies that rely on a particular supervisory level of employee cannot demonstrate the coherent implications of a correlation between strategic management and performance management systems in the public sector. Thus, it can be hypothesized that government employee perceptions of the linkages between each type of strategic management component and the performance management system are likely to be different according to the managerial or supervisory level of the employee. This is the second objective explored in this study.

\subsection{Research Questions and Framework}

The following research questions are posed:

1) Do agencies with a higher level of well-organized and functioning strategic management elements develop more advanced levels of performance management systems? Do strategic management components contribute to the development of performance management systems in the public sector?

2) How each strategic management component correlates with the three dimensions of performance management systems (performance-based promotions or rewards, fairness and accuracy of performance appraisal, and managerial efforts to improve performance) in the public sector?

3) How are government employee perceptions of the relationship between elements of strategic management and performance management systems different across the five supervisor levels (non-supervisors, team leaders, supervisors, managers and executives)?

The findings from this study will contribute to the body of strategic planning-performance literature by exploring the relationship between strategic management components and performance management systems. By illustrating the differing perceptions of the linkage across government employee managerial levels, this study will suggest clear and practical implications for managers in the public sector whose primary responsibilities are to develop strategic planning and management processes and performance management systems. This study will describe the data sample, variables and methodology used in the research model. Key findings from a series of regression analyses will be discussed, and suggestions for future research to address the limitations of this study will be given.

\section{Variables and Operationalization}

\subsection{Dependent Variables}

The first dependent variable, "performance-based promotions or rewards," is constructed from two survey questions by dividing the sum of the responses to the questions by the number of questions. The dependent variable measures the degree to which employees perceive that their rewards and promotions are based on their individual performance and merit. The questions address whether "promotions in my work unit are based on merit" (Q22) and whether "employees are rewarded for providing high-quality products and services to customers" (Q25). All questions are measured on a Likert-type five-point scale from "strongly disagree" (1) to "strongly agree" (5). The variable has a range from one to five. The mean values of the two questions are 3.07 (Q22) and 3.29 (Q25), as shown in Table 1. This study conducts a scale reliability analysis for the questions. The results show a Cronbach's alpha of 0.7709 , indicating a moderate level of internal reliability. Furthermore, as shown in Table 2, a factor analysis of the two items shows a one-factor solution, and its factor loading is 0.7146 .

The second dependent variable, "fairness and accuracy of performance appraisal," is constructed from two survey questions by dividing the sum of the responses to the questions by the number of questions. The dependent variable measures the degree to which employees perceive their performance appraisal systems in agencies to be fair and accurate. The questions address whether "in my work unit, differences in performance are recognized in a meaningful way" (Q28) and whether "my performance appraisal is a fair reflection of my performance" (Q29). All questions are measured on a Likert-type five-point scale from "strongly disagree" (1) to "strongly agree" (5). The variable has a range from one to five. The mean values of these two questions are 2.98 (Q28) and 3.64 (Q29), as shown in Table 1. This study conducts a scale reliability analysis for the two questions. The results show a Cronbach's alpha of 0.6802, indicating a moderate level of internal reliability. Furthermore, as shown in Table 2, a factor analysis of the two items shows a one-factor solution, and its factor loading is 0.6250 .

The third dependent variable, "managerial efforts to improve performance," is constructed from two survey questions by dividing the sum of the responses to the questions by the number of questions. The dependent variable measures the degree to which employees perceive managers or supervisors as making efforts to improve their performance. The questions address whether "discussions with my supervisor/team leader about 
my performance are worthwhile" (Q30) and whether "supervisors/team leaders provide employees with constructive suggestions to improve their job performance" (Q46). All questions are measured on a Likert-type five-point scale from "strongly disagree" (1) to "strongly agree" (5). The variable has a range from one to five. The mean values of the two questions are $3.49(\mathrm{Q} 30)$ and $3.52(\mathrm{Q} 46)$, as shown in Table 1. This study conducts a scale reliability analysis for the two questions. The results show a Cronbach's alpha of 0.7805 , indicating a moderate level of internal reliability. Furthermore, as shown in Table 2, a factor analysis of the two items shows a one-factor solution, and its factor loading is 0.7279 .

\subsection{Independent Variables}

The independent variables identify the major elements of the strategic planning and management process of public agencies. The independent variables of this study try to measure the extent to which government employees perceive quality and achievement in each element of the strategic planning and management process in their agencies. Independent variables are measured by the responses to the following five survey items: "Employees have a feeling of personal empowerment with respect to work processes" (Q24), "Managers communicate the goals and priorities of the organization" (Q38), "Managers review and evaluate the organization's process toward meeting its goals and objectives" (Q39), "How satisfied are you with your involvement in decisions that affect your work?" (Q55), and "How satisfied are you with the information you receive from management on what's going on in your organization?" (Q56) All questions are measured on a Likert-type five-point scale from "strongly disagree" or "very dissatisfied" (1) to "strongly agree" or "very satisfied" (5). The variables have a range from one to five. The mean values of the five survey items are 3.22 (Q24), 3.51 (Q38), 3.56 (Q39), 3.42 (Q55), and 3.25 (Q56), as shown in Table 1.

\subsection{Control Variables}

This study controls for several individual-level factors, such as government employee organizational tenure, pay grade, age and gender. The average organizational tenure of full-time employees is measured by six scales, where $1=$ less than one year, $2=$ one to three years, $3=$ four to five years, $4=$ six to ten years, $5=$ eleven to twenty years, and $6=0$ ver twenty years. Pay grade is measured by seven scales, where 1 indicates the federal wage system; 2 indicates GS one to six; 3 indicates GS seven to twelve; 4 indicates GS thirteen to fifteen; 5 indicates senior executive service; 6 indicates senior level, scientific or professional; and 7 indicates other pay grades. Age is measured by five scales, where $1=$ under $29,2=30-39,3=40-49,4=50-59$, and $5=$ over 60 . The gender variable is a dichotomous variable, where 0 indicates female employees and 1 indicates male employees. In addition, the models control for an institutional location variable as an organizational-level factor. The location variable is a dichotomous variable ( 1 for field agencies and 0 for headquarters).

Table 1. Descriptive statistics

\begin{tabular}{ccccc}
\hline Variables & Mean & Standard Deviation & Minimum & Maximum \\
\hline Q22 & 3.07 & 1.19 & 1 & 5 \\
Q25 & 3.29 & 1.15 & 1 & 5 \\
Q28 & 2.98 & 1.10 & 1 & 5 \\
Q29 & 3.64 & 1.08 & 1 & 5 \\
Q30 & 3.49 & 1.14 & 1 & 5 \\
Q46 & 3.52 & 1.01 & 1 & 5 \\
Q24 & 3.22 & 1.07 & 1 & 5 \\
Q38 & 3.51 & 1.07 & 1 & 5 \\
Q39 & 3.56 & 0.98 & 1 & 5 \\
Q55 & 3.42 & 1.13 & 1 & 5 \\
Q56 & 3.25 & 1.14 & 1 & 5 \\
Tenure & 5.51 & 1.14 & 1 & 6 \\
Pay Grade & 3.54 & 0.99 & 1 & 7 \\
Age & 3.41 & 0.88 & 0 & 5 \\
Gender & 0.46 & 0.41 & 0 & 1 \\
Location & 0.63 & 0.44 & & 1 \\
\hline
\end{tabular}


Table 2. Factor analysis results for dependent variables

\begin{tabular}{lc}
\hline \multicolumn{1}{c}{ Variables } & Factor Loading \\
\hline Performance-based Promotions or Rewards & 0.7146 \\
Promotions in my work unit are based on merit. (Q22) & 0.7146 \\
Employees are rewarded for providing high quality products and services to customers. (Q25) & \\
Cronbach's alpha: 0.7709 & 0.6250 \\
Fairness and Accuracy of Performance Appraisal & 0.6250 \\
In my work unit, differences in performance are recognized in a meaningful way. (Q28) & \\
My performance appraisal is a fair reflection of my performance. (Q29) & 0.7279 \\
Cronbach's alpha: 0.6802 & 0.7279 \\
Managerial Efforts on Improvement of Performance & \\
Discussions with my supervisor/ team leader about my performance are worthwhile. (Q30) \\
Supervisors/ team leaders provide employees with constructive suggestions to improve their job performance. (Q46) \\
Cronbach's alpha: 0.7805
\end{tabular}

\section{Data Sample and Methodology}

\subsection{Data Source and Sample}

This study explores the data from the 2008 Federal Human Capital Survey (FHCS), conducted by the U.S. Office of Personnel Management (OPM). The FHCS survey has been distributed to full-time government employees in the agencies represented by the President's Management Council (PMC) every two years since 2002. The survey measures government employee perceptions of organizational behavior and addresses outcome variables such as performance, satisfaction, turnover intention, managerial capacity, leadership, strategic planning and implementation. Five independent variables based on strategic planning components, three dependent variables based on performance management systems, and the control variables used in the regression models are constructed from the 2008 FHCS data.

The total number of employees who received the 2008 FHCS is 417,218. Approximately 212,223 employees (51\%) completed the survey. This study excludes those respondents who did not answer all of the survey questions. The total number of the final sample that was used in a series of regression models is 208,841 , including non-supervisors $(116,216)$, team leaders $(28,853)$, supervisors $(37,702)$, managers $(21,188)$, and executives $(4,882)$.

\subsection{Methodology}

A series of ordinary least squares (OLS) regression analyses was conducted to address the proposed hypotheses and research questions. The study models explore the correlation between the three dependent variables (performance-based promotions or rewards, fairness and accuracy of performance appraisal, and managerial effort to improve performance) and the independent factors of the strategic management components.

All survey questions used in the construction of the three dependent variables were ordinary variables measured on a five-point Likert-type scale from 1 (strongly disagree) to 5 (strongly agree). Because ordinal variables are not continuous variables, using OLS regression to explore ordinal dependent variables violates the fundamental assumptions of OLS regression and is likely to present biased coefficients and misleading results. Each of the three dependent variables was therefore constructed using average scores of the two relevant survey questions. Therefore, this study considers the dependent variables as continuous ones and uses OLS regression rather than ordered probit analysis.

The purpose of this study is to explore differing government employee perceptions of the relationship between strategic management components and performance management systems, according to hierarchical supervisory levels. The five managerial levels include non-supervisors, team leaders, supervisors, managers and executives. A total of 15 regression analyses were conducted for the three dependent variables and the five managerial levels. 


\section{Model Specification and Results}

This study separates the correlations between strategic management components and the three dependent variables representing dimensions of performance management systems by the five supervisory levels. Table 3 presents the regression results for non-supervisors (Table 4 represents regression results for team leaders, Table 5 for supervisors, Table 6 for managers, and Table 7 for executives). The results section discusses how each independent variable shows relatively different correlations with each of the three dependent variables of performance management systems across government employee managerial levels. The coefficients of strategic planning components, independent variables identified by the regression analyses results, are compared.

\subsection{Regression Results for Performance-Based Promotions or Rewards across Employee Managerial Levels}

The first dependent variable, performance-based promotions or rewards, measures the degree to which government employees perceive that their rewards and promotions are based on their performance and merit within the organization. The second column of each of the regression output tables (Table 3-7) identifies how employee perceptions of the relationship between each of the five strategic management components and the performance-based promotions or rewards are relatively different across the five supervisory levels (non-supervisors, team leaders, supervisors, managers and executives). Employees at different managerial levels show different magnitudes of correlation, but all correlations are positively and statistically significant at the 0.01 level.

The non-supervisor perception of the correlation $(0.371, \mathrm{p}<0.01)$ between the level of personal empowerment with respect to work processes and the quality of performance-based promotions or rewards system in agencies is the highest of the five managerial levels, as shown in Table 3. Compared to the other managerial levels, managers who report a higher level of manager communication regarding the goals and priorities of the organization are likely to report a higher level of quality in performance-based promotions or rewards in their agencies. The coefficient $(0.099, \mathrm{p}<0.01)$ is shown in Table 6 . The coefficient $(0.124, \mathrm{p}<0.01)$ of executives represents a stronger correlation between the level of manager review and evaluation regarding organizational progress (toward meeting organizational goals and objectives) and the quality of performance-based promotions or rewards systems compared with the coefficients of the other managerial levels, as shown in Table 7. The coefficient $(0.165, \mathrm{p}<0.01)$ of team leaders with regard to the link between the level of satisfaction with their involvement in decisions that affect their work and the quality of performance-based promotions or rewards systems represents a stronger correlation compared with the coefficients of the other managerial levels, as shown in Table 4. The supervisor perception of the correlation $(0.132, \mathrm{p}<0.01)$ between the level of satisfaction with the information received from management regarding organizational activity and the quality of performance-based promotions or rewards system in agencies is the highest of the five managerial levels of employees, as shown in Table 5.

\subsection{Regression Results for Fairness and Accuracy of Performance Appraisal across Employee Managerial Levels}

The second dependent variable, fairness and accuracy of performance appraisal, measures the extent to which employees perceive their performance systems to be fair and accurate. The third column of each of the regression output tables (Table 3-7) represents how employee perceptions of the correlations between each of the five strategic management components and the fairness and accuracy of performance appraisal differ across the five supervisory levels. The results demonstrate that employees at different managerial levels show different magnitudes of correlation, but all correlations are positively and statistically significant at the 0.01 level.

Executive perception of the correlation $(0.277, \mathrm{p}<0.01)$ between the level of personal empowerment with respect to work processes and the quality of fairness and accuracy of the performance appraisal system is the highest of the five managerial levels of employees, as shown in Table 7. Managers who report a higher level of manager communication regarding the goals and priorities of the organization are more likely to report a higher level of quality of the fairness and accuracy of performance appraisal systems in their agencies. The coefficient $(0.078$, $\mathrm{p}<0.01)$ is shown at Table 6 . Table 6 confirms that the coefficient $(0.129, \mathrm{p}<0.01)$ of managers represents a stronger correlation between the level of manager review and evaluation regarding the organization's progress toward meeting its goals and objectives and the quality of fairness and accuracy of the performance appraisal system compared with those of the other managerial levels. The coefficient $(0.206, \mathrm{p}<0.01)$ of non-supervisors represents a stronger correlation than that of any other managerial level regarding the link between the level of satisfaction with non-supervisors' involvement in decisions that affect their work and the quality of fairness and accuracy of performance appraisal systems, as shown in Table 3. The executive perception of the correlation $(0.103, p<0.01)$ between the level of satisfaction with the information they receive from management regarding 
organizational activity and the quality of fairness and accuracy of the performance appraisal system is the highest of all five managerial levels of employees, as shown in Table 7.

\subsection{Regression Results for Managerial Efforts to Improve Performance across Employee Managerial Levels}

The third dependent variable, managerial efforts to improve performance, measures the degree to which employees perceive that managers or supervisors make efforts to improve employee performance. The fourth column of each of the regression output tables (Table 3-7) shows employee perceptions of the relationship between each of the five strategic management components and managerial efforts to improve performance. Perceptions differ across the five managerial levels. The tables illustrate that employees at different managerial levels show different magnitudes of correlation, but all correlations are positively and statistically significant at the 0.01 level.

The non-supervisor perception of the correlation $(0.240, p<0.01)$ between the level of personal empowerment with respect to work processes and the quality of managerial efforts to improve performance is the highest of all five managerial levels of employees, as shown in Table 3. Managers who report a higher level of manager communication regarding the goals and priorities of the organization are more likely to report a higher level of quality of managerial efforts to improve performance. The coefficient $(0.114, p<0.01)$ is shown in Table 6 . Table 7 confirms that the coefficient $(0.169, \mathrm{p}<0.01)$ of executives represents a stronger correlation between the level of manager review and evaluation regarding an organization's progress toward meeting its goals and objectives and the quality of managerial efforts to improve performance compared with the coefficients of the other managerial levels. The coefficient $(0.231, \mathrm{p}<0.01)$ of non-supervisors represents a stronger correlation than that of any other managerial level regarding the link between the level of satisfaction with non-supervisor involvement in decisions that affect their work and the quality of managerial efforts to improve performance in agencies, as shown in Table 3. Executive perception of the correlation $(0.145, p<0.01)$ between the level of satisfaction with the information they receive from management regarding organizational activity and the quality of managerial efforts to improve performance is the highest of all five managerial levels of employees, as shown in Table 7.

Table 8 shows the managerial levels of employees with the strongest or weakest perceptions of the correlation between each strategic management component and the performance-based management variables. Managerial levels are arranged in order of magnitude regarding the relevant correlation. Employees included in the managerial level farthest to the left perceive and report the strongest correlation between each strategic management component and the relevant dimension of performance management systems. One distinct point, shown in Table 8, is that as the managerial level ascends, there is a growing employee perception of a correlation between the level of manager evaluation regarding an organization's progress toward its goals and objectives and the quality of managerial efforts to improve performance. Conversely, as the supervisory level descends, employee perception of the relationship between the levels of satisfaction with their involvement in decisions and the quality of managerial efforts to improve performance also grows.

Table 3. Non-supervisors' results of regression analysis for performance management system

\begin{tabular}{lccc}
\hline & DV1 & DV2 & DV3 \\
\hline \multicolumn{1}{c}{ Strategic Management Components } & & \\
\hline Employees have a feeling of personal empowerment with respect to work processes (q 24) & $0.371^{* * *}$ & $0.272^{* * *}$ & $0.240^{* * *}$ \\
& $(0.002)$ & $(0.002)$ & $(0.002)$ \\
Managers communicate the goals and priorities of the organization (q 38) & $0.088^{* * *}$ & $0.068^{* * *}$ & $0.111^{* * *}$ \\
& $(0.003)$ & $(0.003)$ & $(0.003)$ \\
Mangers review and evaluate the organization's progress toward meeting its goals and & $0.108^{* * *}$ & $0.105^{* * *}$ & $0.130^{* * *}$ \\
objectives (q 39) & $(0.003)$ & $(0.003)$ & $(0.003)$ \\
How satisfied are you with your involvement in decisions that affect your work? (q 53) & $0.162^{* * *}$ & $0.206^{* * *}$ & $0.231^{* * *}$ \\
& $(0.002)$ & $(0.002)$ & $(0.002)$ \\
How satisfied are you with the information you receive from management on what's going & $0.119^{* * *}$ & $0.082^{* * *}$ & $0.099^{* * * *}$ \\
on in your organization? (q 54) & $(0.002)$ & $(0.002)$ & $(0.002)$ \\
\hline \multicolumn{1}{c}{ Individual-Level Control Factors } & & & \\
\hline Tenure & $-0.010^{* * *}$ & $-0.014^{* * *}$ & $-0.023^{* * *}$ \\
& $(0.002)$ & $(0.002)$ & $(0.002)$ \\
Pay grade & $0.051^{* * *}$ & $0.016^{* * *}$ & $0.012^{* * *}$ \\
& $(0.002)$ & $(0.002)$ & $(0.002)$ \\
\hline
\end{tabular}




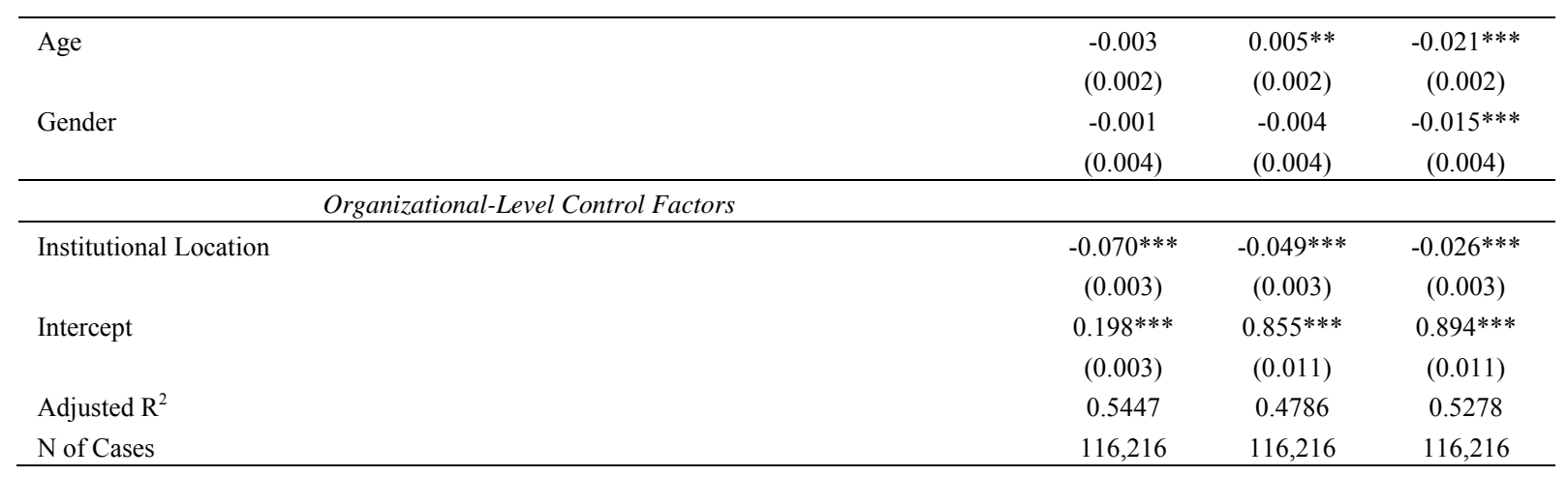

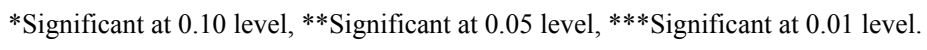

The numbers in parentheses refer to standard errors.

DV1 (First Dependent Variable): Performance-based Promotions or Rewards.

DV2 (Second Dependent Variable): Fairness and Accuracy of Performance Appraisal.

DV3 (Third Dependent Variable): Managerial Efforts on Improvement of Performance.

Table 4. Team leaders' results of regression analysis for performance management system

\begin{tabular}{|c|c|c|c|}
\hline & DV1 & DV2 & DV3 \\
\hline \multicolumn{4}{|l|}{ Strategic Management Components } \\
\hline Employees have a feeling of personal empowerment with respect to work processes (q24) & $\begin{array}{c}0.351 * * * \\
(0.004)\end{array}$ & $\begin{array}{c}0.254 * * * \\
(0.004)\end{array}$ & $\begin{array}{c}0.227 * * * \\
(0.004)\end{array}$ \\
\hline Managers communicate the goals and priorities of the organization (q38) & $\begin{array}{c}0.086^{* * *} \\
(0.005)\end{array}$ & $\begin{array}{c}0.056^{* * *} \\
(0.005)\end{array}$ & $\begin{array}{c}0.083^{* * *} \\
(0.005)\end{array}$ \\
\hline $\begin{array}{l}\text { Mangers review and evaluate the organization's progress toward meeting its goals and } \\
\text { objectives (q39) }\end{array}$ & $\begin{array}{c}0.109^{* * *} \\
(0.006)\end{array}$ & $\begin{array}{c}0.115^{* * *} \\
(0.005)\end{array}$ & $\begin{array}{c}0.136^{* * *} \\
(0.005)\end{array}$ \\
\hline How satisfied are you with your involvement in decisions that affect your work? (q53) & $\begin{array}{c}0.165 * * * \\
(0.005)\end{array}$ & $\begin{array}{c}0.184 * * * \\
(0.004)\end{array}$ & $\begin{array}{c}0.224 * * * \\
(0.004)\end{array}$ \\
\hline $\begin{array}{l}\text { How satisfied are you with the information you receive from management on what's going } \\
\text { on in your organization? (q54) }\end{array}$ & $\begin{array}{c}0.118^{* * *} \\
(0.005)\end{array}$ & $\begin{array}{c}0.084 * * * \\
(0.005)\end{array}$ & $\begin{array}{c}0.100^{* * *} \\
(0.004)\end{array}$ \\
\hline \multicolumn{4}{|l|}{ Individual-Level Control Factors } \\
\hline Tenure & $\begin{array}{c}0.004 \\
(0.005)\end{array}$ & $\begin{array}{c}-0.015^{* * *} \\
(0.004)\end{array}$ & $\begin{array}{c}-0.021 * * * \\
(0.004)\end{array}$ \\
\hline Pay grade & $\begin{array}{c}0.070 * * * \\
(0.004)\end{array}$ & $\begin{array}{c}0.022 * * * \\
(0.003)\end{array}$ & $\begin{array}{c}0.013 * * * \\
(0.003)\end{array}$ \\
\hline Age & $\begin{array}{c}-0.014 * * \\
(0.006)\end{array}$ & $\begin{array}{c}0.014 * * * \\
(0.006)\end{array}$ & $\begin{array}{l}-0.011^{*} \\
(0.006)\end{array}$ \\
\hline Gender & $\begin{array}{c}0.002 \\
(0.011) \\
\end{array}$ & $\begin{array}{c}0.009 \\
(0.010) \\
\end{array}$ & $\begin{array}{l}0.020^{*} \\
(0.010) \\
\end{array}$ \\
\hline Organizational-Level Control Factors & & & \\
\hline Institutional Location & $\begin{array}{c}-0.077 * * * \\
(0.007)\end{array}$ & $\begin{array}{c}-0.070 * * * \\
(0.007)\end{array}$ & $\begin{array}{c}-0.033 * * * \\
(0.007)\end{array}$ \\
\hline Intercept & $\begin{array}{c}0.186^{* * *} \\
(0.025)\end{array}$ & $\begin{array}{c}0.974 * * * \\
(0.024)\end{array}$ & $\begin{array}{c}1.076^{* * *} \\
(0.024)\end{array}$ \\
\hline Adjusted $\mathrm{R}^{2}$ & 0.5075 & 0.4372 & 0.4810 \\
\hline $\mathrm{N}$ of Cases & 28,853 & 28,853 & 28,853 \\
\hline
\end{tabular}

*Significant at 0.10 level, **Significant at 0.05 level, $* * *$ Significant at 0.01 level.

The numbers in parentheses refer to standard errors.

DV1 (First Dependent Variable): Performance-based Promotions or Rewards.

DV2 (Second Dependent Variable): Fairness and Accuracy of Performance Appraisal.

DV3: (Third Dependent Variable): Managerial Efforts on Improvement of Performance. 
Table 5. Supervisors' results of regression analysis for performance management system

\begin{tabular}{|c|c|c|c|}
\hline & DV1 & DV2 & DV3 \\
\hline \multicolumn{4}{|l|}{ Strategic Management Components } \\
\hline Employees have a feeling of personal empowerment with respect to work processes (q24) & $\begin{array}{c}0.351^{* * *} \\
(0.004)\end{array}$ & $\begin{array}{c}0.255^{* * *} \\
(0.003)\end{array}$ & $\begin{array}{c}0.188^{* * *} \\
(0.003)\end{array}$ \\
\hline Managers communicate the goals and priorities of the organization (q38) & $\begin{array}{c}0.082 * * * \\
(0.005)\end{array}$ & $\begin{array}{c}0.060^{* * *} \\
(0.005)\end{array}$ & $\begin{array}{c}0.096 * * * \\
(0.004)\end{array}$ \\
\hline $\begin{array}{l}\text { Mangers review and evaluate the organization's progress toward meeting its goals and } \\
\text { objectives (q39) }\end{array}$ & $\begin{array}{c}0.112 * * * \\
(0.005)\end{array}$ & $\begin{array}{c}0.128 * * * \\
(0.005)\end{array}$ & $\begin{array}{c}0.150 * * * \\
(0.004)\end{array}$ \\
\hline How satisfied are you with your involvement in decisions that affect your work? (q53) & $\begin{array}{l}0.139 * * * \\
(0.004)\end{array}$ & $\begin{array}{c}0.170 * * * \\
(0.004)\end{array}$ & $\begin{array}{c}0.186^{* * *} \\
(0.003)\end{array}$ \\
\hline $\begin{array}{l}\text { How satisfied are you with the information you receive from management on what's going } \\
\text { on in your organization? (q54) }\end{array}$ & $\begin{array}{c}0.132 * * * \\
(0.004)\end{array}$ & $\begin{array}{c}0.092^{* * *} \\
(0.004)\end{array}$ & $\begin{array}{c}0.113 * * * \\
(0.004)\end{array}$ \\
\hline \multicolumn{4}{|l|}{ Individual-Level Control Factors } \\
\hline Tenure & $\begin{array}{c}0.027 * * * \\
(0.004)\end{array}$ & $\begin{array}{c}-0.013 * * * \\
(0.004)\end{array}$ & $\begin{array}{c}-0.028 * * * \\
(0.003)\end{array}$ \\
\hline Pay grade & $\begin{array}{c}0.056^{* * *} \\
(0.003)\end{array}$ & $\begin{array}{c}0.018 * * * \\
(0.002)\end{array}$ & $\begin{array}{l}0.004 * \\
(0.002)\end{array}$ \\
\hline Age & $\begin{array}{c}-0.024 * * * \\
(0.005)\end{array}$ & $\begin{array}{c}0.024 * * * \\
(0.004)\end{array}$ & $\begin{array}{c}-0.013^{* * *} \\
(0.004)\end{array}$ \\
\hline Gender & $\begin{array}{l}0.014^{*} \\
(0.008) \\
\end{array}$ & $\begin{array}{c}0.033 * * * \\
(0.007) \\
\end{array}$ & $\begin{array}{r}0.010 \\
(0.007) \\
\end{array}$ \\
\hline Organizational-Level Control Factors & & & \\
\hline Institutional Location & $\begin{array}{c}-0.051 * * * \\
(0.006)\end{array}$ & $\begin{array}{c}-0.065 * * * \\
(0.006)\end{array}$ & $\begin{array}{c}-0.018 * * * \\
(0.006)\end{array}$ \\
\hline Intercept & $\begin{array}{c}0.315^{* * *} \\
(0.022)\end{array}$ & $\begin{array}{c}0.942 * * * \\
(0.021)\end{array}$ & $\begin{array}{c}1.261^{* * *} \\
(0.020)\end{array}$ \\
\hline Adjusted $\mathrm{R}^{2}$ & 0.5042 & 0.4363 & 0.4895 \\
\hline $\mathrm{N}$ of Cases & 37,702 & 37,702 & 37,702 \\
\hline
\end{tabular}

*Significant at 0.10 level, ${ }^{*}$ Significant at 0.05 level, ${ }^{* *}$ Significant at 0.01 level.

The numbers in parentheses refer to standard errors.

DV1 (First Dependent Variable): Performance-based Promotions or Rewards.

DV2 (Second Dependent Variable): Fairness and Accuracy of Performance Appraisal.

DV3: (Third Dependent Variable): Managerial Efforts on Improvement of Performance.

Table 6. Managers' results of regression analysis for performance management system

\begin{tabular}{lccc}
\hline & DV1 & DV2 & DV3 \\
\hline \multicolumn{1}{c}{ Strategic Management Components } & & & \\
\hline Employees have a feeling of personal empowerment with respect to work processes (q24) & $0.355^{* * *}$ & $0.265^{* * *}$ & $0.194^{* * *}$ \\
& $(0.005)$ & $(0.005)$ & $(0.004)$ \\
Managers communicate the goals and priorities of the organization (q38) & $0.099^{* * *}$ & $0.078^{* * *}$ & $0.114^{* * *}$ \\
& $(0.006)$ & $(0.006)$ & $(0.006)$ \\
Mangers review and evaluate the organization's progress toward meeting its goals and & $0.110^{* * *}$ & $0.129^{* * *}$ & $0.153^{* * *}$ \\
objectives (q39) & $(0.006)$ & $(0.006)$ & $(0.006)$ \\
How satisfied are you with your involvement in decisions that affect your work? (q53) & $0.126^{* * *}$ & $0.155^{* * *}$ & $0.170^{* * *}$ \\
& $(0.005)$ & $(0.005)$ & $(0.004)$ \\
How satisfied are you with the information you receive from management on what's going & $0.110^{* * *}$ & $0.079^{* * *}$ & $0.108^{* * *}$ \\
on in your organization? (q54) & $(0.005)$ & $(0.005)$ & $(0.005)$ \\
\hline \multicolumn{1}{c}{ Individual-Level Control Factors } & & $-0.022^{* * *}$ & $-0.012^{* * * *}$ \\
\hline Tenure & $0.028^{* * *}$ & $-0.005)$ & $(0.004)$ \\
Pay grade & $(0.005)$ & $(0.005)$ & $-0.008^{* *}$ \\
& $0.055^{* * *}$ & $0.009^{* *}$ & $(0.004)$ \\
\hline
\end{tabular}




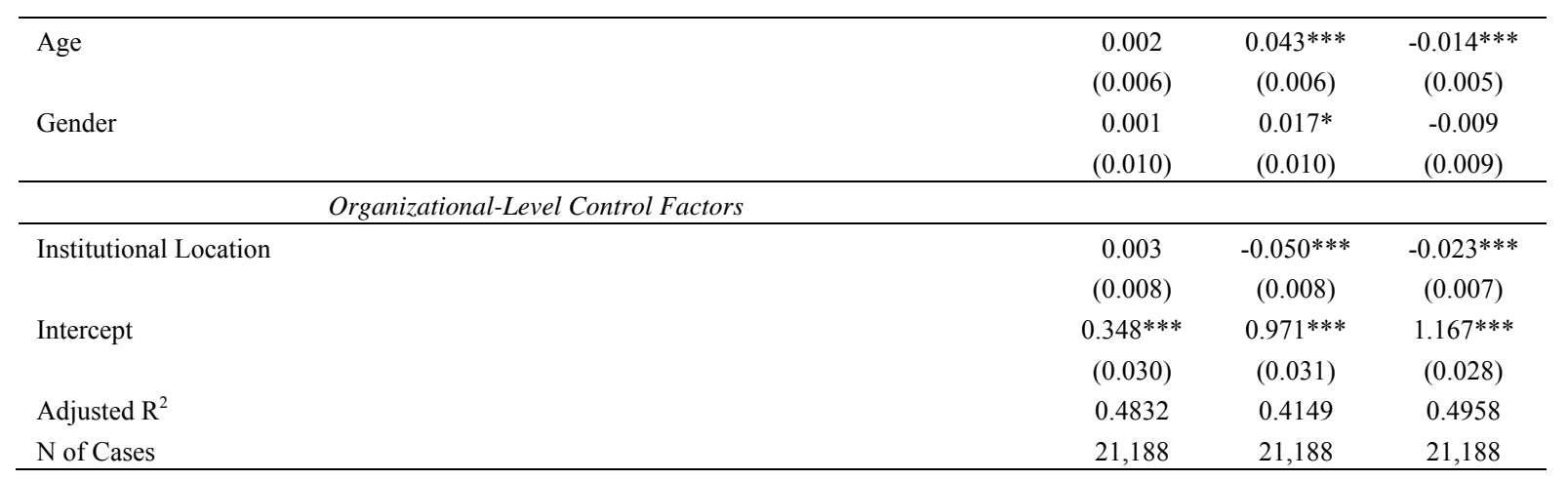

*Significant at 0.10 level, **Significant at 0.05 level, ***Significant at 0.01 level.

The numbers in parentheses refer to standard errors.

DV1 (First Dependent Variable): Performance-based Promotions or Rewards.

DV2 (Second Dependent Variable): Fairness and Accuracy of Performance Appraisal.

DV3: (Third Dependent Variable): Managerial Efforts on Improvement of Performance.

Table 7. Executives' results of regression analysis for performance management system

\begin{tabular}{|c|c|c|c|}
\hline & DV1 & DV2 & DV3 \\
\hline \multicolumn{4}{|l|}{ Strategic Management Components } \\
\hline Employees have a feeling of personal empowerment with respect to work processes (q24) & $\begin{array}{c}0.361 * * * \\
(0.010)\end{array}$ & $\begin{array}{c}0.277 * * * \\
(0.011)\end{array}$ & $\begin{array}{c}0.209 * * * \\
(0.010)\end{array}$ \\
\hline Managers communicate the goals and priorities of the organization (q38) & $\begin{array}{c}0.076^{* * *} \\
(0.013)\end{array}$ & $\begin{array}{c}0.074 * * * \\
(0.015)\end{array}$ & $\begin{array}{c}0.101^{* * *} \\
(0.013)\end{array}$ \\
\hline $\begin{array}{l}\text { Mangers review and evaluate the organization's progress toward meeting its goals and } \\
\text { objectives (q39) }\end{array}$ & $\begin{array}{c}0.124 * * * \\
(0.013)\end{array}$ & $\begin{array}{c}0.100^{* * *} \\
(0.014)\end{array}$ & $\begin{array}{c}0.169 * * * \\
(0.013)\end{array}$ \\
\hline How satisfied are you with your involvement in decisions that affect your work? (q53) & $\begin{array}{c}0.151^{* * *} \\
(0.011)\end{array}$ & $\begin{array}{c}0.176^{* * *} \\
(0.012)\end{array}$ & $\begin{array}{c}0.158 * * * \\
(0.011)\end{array}$ \\
\hline $\begin{array}{l}\text { How satisfied are you with the information you receive from management on what's going } \\
\text { on in your organization? (q54) }\end{array}$ & $\begin{array}{c}0.085^{* * *} \\
(0.011) \\
\end{array}$ & $\begin{array}{c}0.103 * * * \\
(0.012) \\
\end{array}$ & $\begin{array}{c}0.145^{* * *} \\
(0.011)\end{array}$ \\
\hline \multicolumn{4}{|l|}{ Individual-Level Control Factors } \\
\hline Tenure & $\begin{array}{c}0.012 \\
(0.014)\end{array}$ & $\begin{array}{l}-0.025 \\
(0.016)\end{array}$ & $\begin{array}{c}0.008 \\
(0.014)\end{array}$ \\
\hline Pay grade & $\begin{array}{c}0.057 * * * \\
(0.010)\end{array}$ & $\begin{array}{c}0.013 \\
(0.011)\end{array}$ & $\begin{array}{l}-0.015 \\
(0.010)\end{array}$ \\
\hline Age & $\begin{array}{l}-0.001 \\
(0.016)\end{array}$ & $\begin{array}{l}0.044 * * \\
(0.017)\end{array}$ & $\begin{array}{c}-0.026^{*} \\
(0.016)\end{array}$ \\
\hline Gender & $\begin{array}{c}-0.077 * * * \\
(0.027)\end{array}$ & $\begin{array}{l}-0.050^{*} \\
(0.030)\end{array}$ & $\begin{array}{l}-0.018 \\
(0.027) \\
\end{array}$ \\
\hline Organizational-Level Control Factors & & & \\
\hline Institutional Location & $\begin{array}{c}-0.034 * * \\
(0.016)\end{array}$ & $\begin{array}{c}-0.051 * * * \\
(0.017)\end{array}$ & $\begin{array}{c}0.005 \\
(0.016)\end{array}$ \\
\hline Intercept & $\begin{array}{c}0.591 * * * \\
(0.074)\end{array}$ & $\begin{array}{c}0.916^{* * *} \\
(0.080)\end{array}$ & $\begin{array}{c}0.895^{* * *} \\
(0.072)\end{array}$ \\
\hline Adjusted $\mathrm{R}^{2}$ & 0.5349 & 0.4539 & 0.5322 \\
\hline $\mathrm{N}$ of Cases & 4,882 & 4,882 & 4,882 \\
\hline
\end{tabular}

*Significant at 0.10 level, **Significant at 0.05 level, ${ }^{* *}$ Significant at 0.01 level.

The numbers in parentheses refer to standard errors.

DV1 (First Dependent Variable): Performance-based Promotions or Rewards.

DV2 (Second Dependent Variable): Fairness and Accuracy of Performance Appraisal.

DV3 (Third Dependent Variable): Managerial Efforts on Improvement of Performance. 
Table 8 . Summary of regression analysis results

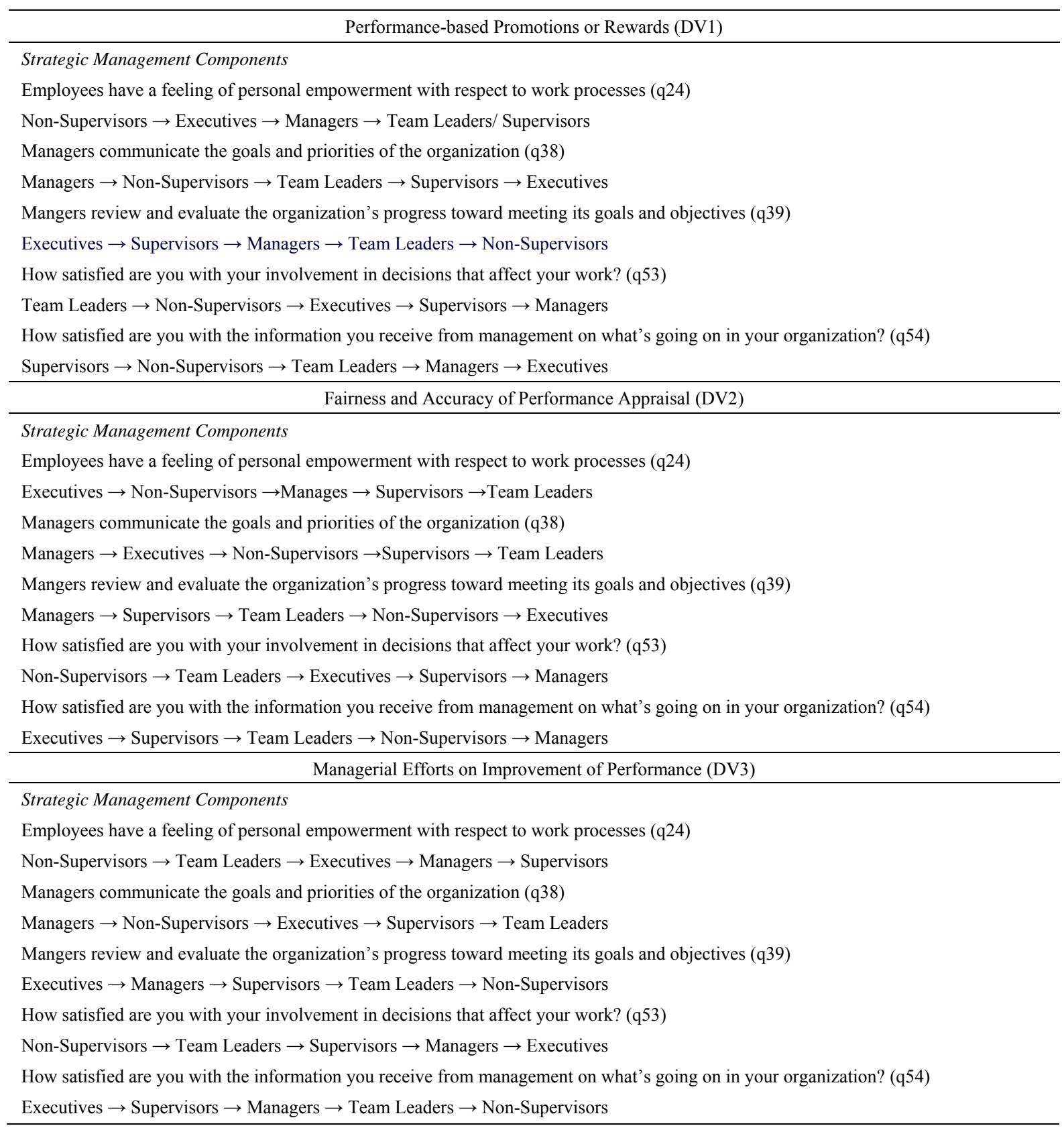

Highly correlated

Weakly correlated

\section{Conclusions and Limitations}

The study aims to estimate the relationship between elements of strategic management processes and performance management systems in U.S. federal agencies. This research explores the correlation between government employee perception of the five types of strategic management components in agencies and three dimensions of performance management systems (performance-based promotions or rewards, fairness and accuracy of performance appraisal, and managerial efforts to improve performance). This study also explores 
whether the correlations differ across employee managerial levels (non-supervisors, team leaders, supervisors, managers and executives).

The regression analysis results show that all five elements of strategic management processes in the models are positively correlated with the three dimensions of performance management systems among all five levels of employee supervisory status. The results indicate that agencies with higher-quality strategic management components are likely to have more advanced performance management systems. This study contributes to the strategic planning-performance literature by exploring the relationship between strategic management components and performance management systems beyond the relationship between strategic planning or management and organizational performance.

A series of regression analyses demonstrates that the linkages differ depending on the managerial level of the employee. Employees at different managerial levels in the public sector perceive and report the correlation between strategic management components with each dimension of the performance management systems differently. Managers in the public sector would benefit from understanding the differing perceptions of government employees regarding the linkage between strategic management components and performance management systems and from having the ability to adjust strategic planning components, depending on managerial levels, to improve performance management systems and organizational performance.

There were limitations to this study that future research should address. First, all independent variables of strategic planning components and all dependent variables of the three dimensions of performance management systems that were used in the series of regression models were entirely based on subjective government employee perceptions. Different results may have been obtained if more objective data had been used. Mono-source biases resulted. Both self-reported responses and government employee social desirability responses could have over- or underestimated measures and correlations among these variables.

Second, causal inferences or estimations of the observed correlations between independent and dependent variables cannot be guaranteed because this study uses cross-sectional data based on one specific year, the 2008 Federal Human Capital Survey. Third, this research does not include other critical components relevant to strategic planning and management, such as stakeholder involvement, monitoring activities, internal and external environmental scanning efforts, the application of feedback from primary stakeholders, and congruence between mandates and missions. Future studies should explore the correlation between strategic planning components not covered in this study and performance management systems in public organizations. Studies that estimate those different correlations according to employee managerial levels will contribute to the strategic planning-performance literature.

The regression results of this study revealed important findings regarding employee perceptions of personal empowerment with respect to work processes for managers in the public sector who are primarily responsible for the development of strategic management and performance management systems in their agencies. The first variable of strategic management, personal empowerment of employees with respect to work processes, has a stronger correlation with the three performance management system variables at all employee managerial levels than the other four variables used in the study. Regardless of government employee supervisory status, employees perceive and report the importance of their autonomy and commitment regarding work processes to be important to the development of a performance-based management system. Future strategic planning-performance studies should focus on the empowerment of employees with respect to work processes and how that empowerment influences and contributes to the development of performance-based management in the public sector.

\section{Acknowledgements}

The author gratefully acknowledges helpful comments and suggestions from three anonymous referees. In addition, my special appreciation goes to Dr. Patria de Lancer Julnes and Dr. George Julnes for their unstinting guidance and support as well as to my life-time supporter, Mi Jang.

\section{References}

Behn, R. D. (2003). Why Measure Performance? Different Purposes Require Different Measures. Public Administration Review, 63(5), 586-606. http://dx.doi.org/10.1111/1540-6210.00322

Berry, F. S., \& Wechsler, B. (1995). State Agencies' Experience with Strategic Planning: Findings from a National Survey. Public Administration Review, 55(2), 159-167. http://dx.doi.org/10.2307/977181

Boal, K. B., \& Bryson, J. M. (1987). Representation Testing and Policy Implications of Planning Process. Strategic Management Journal, 8(3), 211-231. http://dx.doi.org/10.1002/smj.4250080302 
Boston, J., \& Pallot, J. (1997). Linking Strategy and Performance: Developments in the New Zealand Public Sector. Journal of Policy Analysis and Management, 16(3), 382-404. http://dx.doi.org/10.1002/1520-6688(199722)16:3<382::AID-PAM18>3.0.CO;2-S

Bryson, J. M. (2011). Strategic Planning for Public and Nonprofit Organizations: A Guide to Strengthening and Sustaining Organizational Achievement. San Francisco, CA: Jossey-Bass A Wiley Imprint.

Bryson, J. M., \& Roering, W. D. (1987). Applying Private-Sector Strategic Planning in the Public Sector. American Planning Association Journal, 53(1), 9-22. http://dx.doi.org/10.1080/01944368708976631

Chakravarthy, B. S. (1987). On Tailoring a Strategic Planning System to Its Context: Some Empirical Evidence. Strategic Management Journal, 8(6), 517-534. http://dx.doi.org/10.1002/smj.4250080603

Chun, Y. H., \& Rainey, H. G. (2005). Goal Ambiguity and Organizational Performance in U.S. Federal Agencies. Journal of Public Administration Research and Theory, 15(4), 529-557. http://dx.doi.org/10.1093/jopart/mui030

Deyle, R. E. (1994). Conflict, Uncertainty, and the Role of Planning and Analysis in Public Policy Innovation. Policy Studies Journal, 22(3), 457-473. http://dx.doi.org/10.1111/j.1541-0072.1994.tb01481.x

Hendrick, R. (2003). Strategic Planning Environment, Process, and Performance in Public Agencies: A Comprehensive Study of Departments in Milwaukee. Journal of Public Administration Research and Theory, 13(4), 491-519. http://dx.doi.org/10.1093/jopart/mug031

Hosmer, L. T. (1994). Strategic Planning as if Ethics Mattered. Strategic Management Journal, 15(Special Issue Summer), 17-34.

Meier, K. J., O’Toole, L. J., Boyne, G. A., \& Walker, R. M. (2007). Strategic Management and the Performance of Public Organizations: Testing Venerable Ideas against Recent Theories. Journal of Public Administration Research and Theory, 17(3), 357-377. http://dx.doi.org/10.1093/jopart/mul017

Miller, C. C., \& Cardinal, L. B. (1994). Strategic Planning and Firm Performance: A Synthesis of More Than Two Decades of Research. Academy of Management Journal, 37(6), 1649-1665. http://dx.doi.org/10.2307/256804

Moore, M. (1995). Defining Public Value. In Creating Public Value: Strategic Management in Government. Cambridge, MA: Harvard University Press.

Nutt, P. C. (1986). Tactics of Implementation. Academy of Management Journal, 29(2), 230-261. http://dx.doi.org/10.2307/256187

Nutt, P. C., \& Backoff, R. W. (1993). Organizational Publicness and its Implications for Strategic Management. Journal of Public Administration Research and Theory, 3(2), 209-231.

Poister, T. H., \& Streib, G. (2005). Elements of Strategic Planning and Management in Municipal Government: Status after Two Decades. Public Administration Review, 65(1), 45-56. http://dx.doi.org/10.1111/j.1540-6210.2005.00429.x

Rainey, H. G., \& Bozeman, B. (2000). Comparing Public and Private Organizations: Empirical Research and the Power of the A Priori. Journal of Public Administration Research and Theory, 10(2), 447-469. http://dx.doi.org/10.1093/oxfordjournals.jpart.a024276

Ring, P. S., \& Perry, J. L. (1985). Strategic Management in Public and Private Organizations: Implications of Distinctive Contexts and Constraints. Academy of Management Review, 10(2), 276-286.

Shrader, C. B., Taylor, L., \& Dalton, D. R. (1984). Strategic Planning and Organizational Performance: A $\begin{array}{lllll}\text { Critical Appraisal. Journal of } & \text { Management, } & 10(2), & 149-171 .\end{array}$ http://dx.doi.org/10.1177/014920638401000202

Wright, B. E. (2007). Public Service and Motivation: Does Mission Matter? Public Administration Review, 67(1), 54-64. http://dx.doi.org/10.1111/j.1540-6210.2006.00696.x 